\title{
Relationships Between Somatic Cell Count and Intramammary Infection in Buffaloes
}

\author{
P. Moroni, ${ }^{\star 1}$ C. Sgoifo Rossi,† G. Pisoni, ${ }^{\star}$ V. Bronzo, ${ }^{\star}$ B. Castiglioni, $\neq$ and P. J. Boettcher $\ddagger^{2}$ \\ *Department of Animal Pathology, Hygiene and Veterinary Public Health, and \\ †Department of Veterinary Sciences and Technologies for Food Safety, University of Milan, via Celoria 10, 20133 Milan, Italy \\ †Institute of Agricultural Biology and Biotechnology, National Research Council, Milan Palazzo LITA, Milan, Italy
}

\begin{abstract}
The objectives of this study were to evaluate the presence of intramammary infections (IMI) in dairy buffaloes and to examine the relationships among IMI, somatic cell counts (SCC), and milk production traits. Two farms in northern Italy were visited monthly for a complete milking season. Quarter-based milk samples were collected at each visit from 46 buffaloes. A total of 1,912 samples were assessed in this experiment. Samples were cultured for bacterial presence and were tested for SCC and percentages of milk protein and fat. In addition, daily milk yield was recorded from each buffalo. Prevalence of IMI was large; $63 \%$ of quarters were infected. No buffalo remained free from IMI throughout the course of the study. Coagulase-negative staphylococci were the most common pathogen $(66 \%$ of positive samples). The SCC was distinctly greater in infected quarters; $100 \%$ of quarters with SCC $>200,000$ cell/mL had IMI, whereas $98 \%$ of quarters with SCC below this threshold were uninfected. The somatic cell scores (SCS) in these buffaloes were much lower than those commonly observed in dairy cattle. The mean SCS from quarters with IMI was only 2.93 . The highest SCS was observed in quarters infected by streptococci. No drastic decrease in milk yield was observed among infected buffaloes relative to healthy contemporaries. The relatively low SCS and lack of a strong effect on milk yield provide evidence to discourage antibiotic treatment of buffaloes for subclinical IMI during lactation.
\end{abstract}

Key words: buffalo, intramammary infection, somatic cell count

\section{INTRODUCTION}

In Europe, Italy is the main producer of buffalo milk. Reasons for increasing interest in buffalo breeding dur-

\footnotetext{
Received August 1, 2005.

Accepted November 1, 2005.

${ }^{1}$ Corresponding author: paolo.moroni@unimi.it

${ }^{2}$ Current address: Animal Health and Production Section, Joint IAEA/FAO Division, International Atomic Energy Agency, A-1400 Vienna, Austria.
}

ing recent years are 2-fold: 1 ) the popularity of buffalo Mozzarella cheese, and 2) the absence of quotas in the European Community for this production. In addition, buffalo milk is more valuable; farmers typically receive at least twice the price relative to bovine milk. Italian river buffalo (Bubalus bubalis), typically reared in central middle and southern Italy, also have been recently introduced in northern Italy. Italian buffaloes produce small quantities of milk; the average production in a standardized lactation length $(270 \mathrm{~d})$ is about $2,100 \mathrm{~kg}$, and average fat and protein contents are 8.37 and $4.8 \%$, respectively (Associazione Italiana Allevatori, 1999; Catillo et al., 2002).

One of the most costly diseases in dairy production is mastitis, and even though the buffalo has been traditionally considered less susceptible to mastitis than cattle (Wanasinghe, 1985), some researchers have shown similar mastitis frequencies for the 2 species (Kalra and Dhanda, 1964; Badran, 1985; Bansal et al., 1995). Buffaloes have some characteristics that may contribute to greater risk of mastitis. For example, the udder is more pendulous and teats are longer in comparison with cattle. Conversely, the buffaloes have a long narrow teat canal, which may be expected to prevent the invasion of microorganisms.

The type of bacteria most frequently isolated in milk samples of buffaloes, with mastitis in previous studies, has been CNS followed by Corynebacterium spp. and Streptococcus spp. (Chander and Baxi, 1975; Paranjabe and Das, 1986; Saini et al., 1994; Costa et al., 1997; Naiknaware et al., 1998). Staphylococcus aureus was the most important microorganism responsible for mastitis in buffaloes in one study (Jaffery and Rizvi, 1975).

In the bovine, SCC is usually used as an inflammatory indicator to diagnose mastitis. The SCC also has been used for buffaloes in mastitis diagnosis, and in fact, according to previous studies (Dhakalet al., 1992; Singh and Ludri, 2001), it seems probable that a SCC $>200,000 / \mathrm{mL}$ is an indicative value of udder infection. The results obtained by Cerón-Muñoz et al. (2002) showed that elevated SCC has a negative effect on milk and lactose yield in buffaloes. Moreover, the European Union Directives (46/92 and 71/94) set a limit of 400,000 
cells/mL for SCC in buffalo milk when the milk is used for products made with raw milk.

The goals of the present study were 1) to assess the prevalence of IMI in 2 buffalo herds during a complete lactation, 2) to identify the pathogens causing IMI, and 3) to study the phenotypic relationships among udder infection, SCC, and milk production.

\section{MATERIALS AND METHODS}

\section{Animals and Herds}

A total of 46 buffaloes from 2 commercial dairy farms in northern Italy were monitored for an entire lactation (February 2003 to March 2004). The buffaloes selected for evaluation in this study were those that calved between January and May 2003 and could be monitored for a complete lactation (at least 10 mo in milk). The farms were free of brucellosis, tuberculosis, and leucosis. Herd A consisted of 170 lactating buffaloes. Buffaloes were housed in free stalls and a concrete paddock that was routinely flushed with recycled water. Buffaloes were divided into different groups by age and stage of lactation. Two feeding groups were maintained; the first one was designed for high-yielding, first-lactation buffaloes, and the second was designed for lowyielding, older buffaloes and nonlactating heifers. Milking occurred in a double-9 herringbone parlor.

Herd B consisted of 130 lactating buffaloes housed in free stalls with permanent straw bedding. Buffaloes were divided by age until first calving; then, all buffaloes were grouped together. Milking was performed in a double-8 herringbone milking parlor.

\section{Milk Sampling}

Foremilk samples were obtained (February 2003 to March 2004) during monthly visits for the routine testday quality program performed by technicians of the Provincial Breeding Association. Numbered collars were used to identify the buffaloes in each herd. None of the buffaloes studied had evidence of clinical mastitis at the time of sampling. Teat ends were cleaned with chlorhexidine before sampling. First streams of foremilk were discharged, and then $10 \mathrm{~mL}$ of milk was collected aseptically from each teat into sterile vials. Samples were stored at $4^{\circ} \mathrm{C}$ until bacteriological assays and SCC tests were performed. Samples of pooled milk were tested for percentages of fat and protein concentrations. Milk yield $(\mathrm{kg})$ was recorded on the same day by using recording jars in the milking parlor.

\section{Bacteriological Procedures}

Bacteriological culturing of milk samples was performed according to standards of the National Mastitis
Council (NMC, 1999). Ten microliters of each milk sample was spread on blood agar plates (5\% defibrinated sheep blood). Plates were incubated aerobically at $37^{\circ} \mathrm{C}$ and examined after $24 \mathrm{~h}$. Colonies were provisionally identified on the basis of Gram stain, morphology, and hemolysis patterns, and the numbers of each colony type were recorded. Representative colonies were then subcultured on blood agar plates and incubated aerobically at $37^{\circ} \mathrm{C}$ for $24 \mathrm{~h}$ to obtain pure cultures. Catalase and coagulase production was tested for gram-positive cocci. Specific identifications of staphylococci and streptococci were made using commercial micromethods (API Staph and API 20 Strep, BioMérieux, Italy). Gramnegative isolates were identified by using colony morphology, gram-staining characteristics, oxidase, and biochemical reactions on MacConkey's agar and API 20E (BioMerieux).

Contagious pathogens Staph. aureus and Streptococcus agalactiae were considered to cause IMI if at least one colony $(\geq 100 \mathrm{cfu} / \mathrm{mL})$ was isolated. For other microrganisms, IMI was defined by the isolation of $\geq 500 \mathrm{cfu} /$ $\mathrm{mL}$ and 1 to 3 colony types. Milk samples from which $>3$ colony types or $<500 \mathrm{cfu} / \mathrm{mL}$ colonies of any microorganism were isolated were regarded as contaminated or uninfected, respectively. No contaminated samples, however, were found.

\section{Determination of SCC and Percentages of Protein and Fat}

For each milk sample, the SCC was determined by an automated fluorescent microscopic somatic cell counter (Bentley Somacount 150, Bentley Instrument, Italy). Ethidium bromide dye was used for specific binding to DNA in cell nuclei. For statistical analyses, the SCC were converted to SCS using the standard $\log _{2}$ transformation of Ali and Shook (1980). Percentages of milk fat and protein were determined on composite milk samples and assayed by an automated, Fourier transform, infrared absorption spectrophotometric analyzer (Milkoscan, Foss, Hillerød, Denmark).

\section{Statistical Analyses}

Two primary analyses were performed. The first analysis examined factors that were associated with bacterial infection, and the second examined factors associated with SCS. For the analysis of bacterial infection, presence of bacteria in a given quarter was a dichotomous dependent variable. A value of 1 indicated the presence of bacteria, and a value of 0 indicated no infection. The initial model included effects of herd $x$ visit, calendar month of sampling, DIM, lactation number, location of the quarter (i.e., right or left side, front 
Table 1. Distribution of pathogens present among the infected samples $(\mathrm{n}=1,204)$

\begin{tabular}{lcr}
\hline Species & Frequency & $\%$ \\
\hline Coagulase-negative staphylococci & 945 & 78.4 \\
Streptococcus uberis & 147 & 12.3 \\
Streptococcus faecalis & 19 & 1.6 \\
Streptococcus dysgalactiae & 8 & 0.7 \\
Other Streptococcus & 7 & 0.6 \\
Bacillus spp. & 25 & 2.1 \\
Aerococcus viridans & 17 & 1.4 \\
Citrobacter diversus & 13 & 1.1 \\
Clostridium spp. & 7 & 0.6 \\
Proteus spp. & 2 & 0.2 \\
Yeast & 14 & 1.1 \\
\hline
\end{tabular}

or back), milk yield, percentages of fat and protein on sampling day, and random effects of buffalo and quarter to account for repeated observations.

The effect of DIM was based on 2 regression variables: 1) $\mathrm{DIM}$ and 2) $1 / 2\left(3 \times \mathrm{DIM}^{2}-1\right)$. The latter value was the second term in a Legendre polynomial, which is commonly used for evaluation of effects of stage of lactation on dairy traits (Pool et al., 2000). In addition, both herds practiced group calving (although in slightly different seasons); therefore, the ordered number of visits also accounted for some effects of DIM. Lactation number represented 4 classes: 1, 2, 3 to 4 , and $>4$. Data for milk yield and fat and protein percentages were residuals from models accounting for the same factors included in the model for mastitis (except buffalo and quarter). Backwards stepwise logistic regression was used to remove nonsignificant factors $(P>0.15$, based on Wald's test) from the model. The GENMOD procedure of SAS (1996) was used for these analyses.

The second set of analyses examined factors associated with SCS. In this test, the SCS in each quarter was used as the dependent variable, and independent variables in the full model were the same as for the analysis of IMI prevalence with the addition of a variable for infection status. Infection status was defined in 2 ways in separate evaluations: 1 ) as either infected or healthy ( $\mathrm{n}=2)$; and 2) as either healthy or infected by a Streptococcus species, a CNS, or any other bacterial species $(n=4)$. In addition, the combined effects of herd $\times$ visit were considered to be random. Maximum likelihood was used to estimate parameters using the MIXED procedure of SAS. Backwards regression was again used to eliminate nonsignificant factors to arrive at a final model.

\section{RESULTS AND DISCUSSION}

\section{Prevalence of Infection}

Among the 1,912 cultured milk samples that were evaluated in this study, 1,204 (63\%) showed the presence of IMI. Within these positive samples (Table 1),

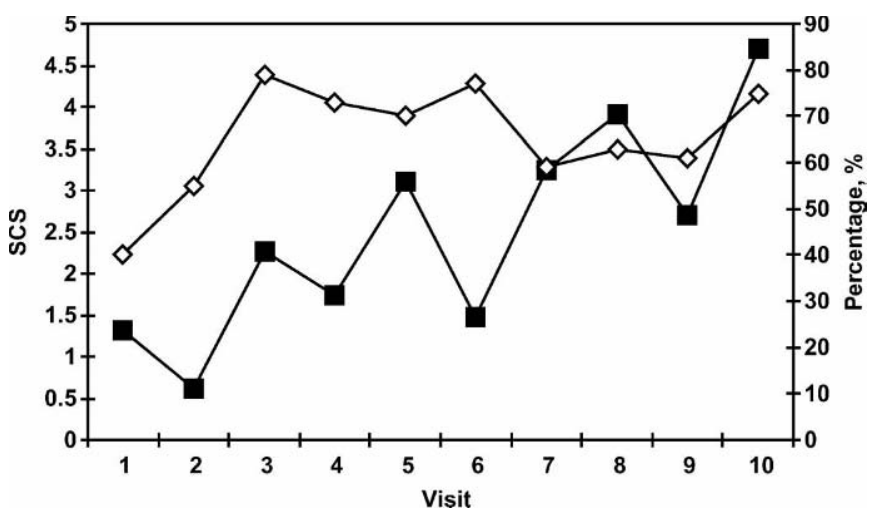

Figure 1. Monthly means for somatic cell score (SCS, 口) and IMI mastitis prevalence ( $\diamond$, per quarter). Monthly standard deviations for SCS ranged from 2.5 to 3.5 .

CNS was the predominant microorganism and was present in $78 \%$ of the cases. Individual species of CNS were not identified. Streptococcus species accounted for $15 \%$ of the IMI, and about $80 \%$ of these were Streptococcus uberis. Remaining IMI were by "other" pathogens, among which only Bacillus spp. were observed in $>20$ samples. Rates of infection by environmental pathogens were similar to those reported for beef cattle (Paape et al., 2000).

None of the 46 buffaloes remained free from infection in all quarters throughout the study. The least infection observed was in a buffalo with 10 positive quarters on 10 test days (i.e., $25 \%$ of tests were positive). In fact, no single quarter remained entirely free from infection during the study. The least prevalence of infection was observed in one quarter with a single positive test during 10 visits. Across all buffaloes, 14 quarters were infected at every test with a maximum of 13 positive tests per quarter. On individual visits, $12 \%$ of buffaloes were free from infection, $11 \%$ were infected in a single quarter, $18 \%$ in 2 quarters, $19 \%$ in 3 quarters, and $40 \%$ in all 4 quarters. Only one buffalo was infected in all quarters at every sampling date, but this buffalo was culled after a single test day. Two other buffaloes were infected in at least $90 \%$ of their quarter samples.

\section{Descriptive Statistics}

Figure 1 shows monthly (in which month is based on stage of lactation) means for SCS and IMI prevalence (on a quarter basis). Both SCS and IMI prevalence were least at the onset of lactation. Prevalence of IMI quickly increased, reaching a maximum of $79 \%$ during the third month of lactation, and then decreased slightly to about $60 \%$ at the sixth visit before increasing to about $75 \%$ during late lactation. The SCS reached a minimum (0.61) during the second month of lactation and gener- 


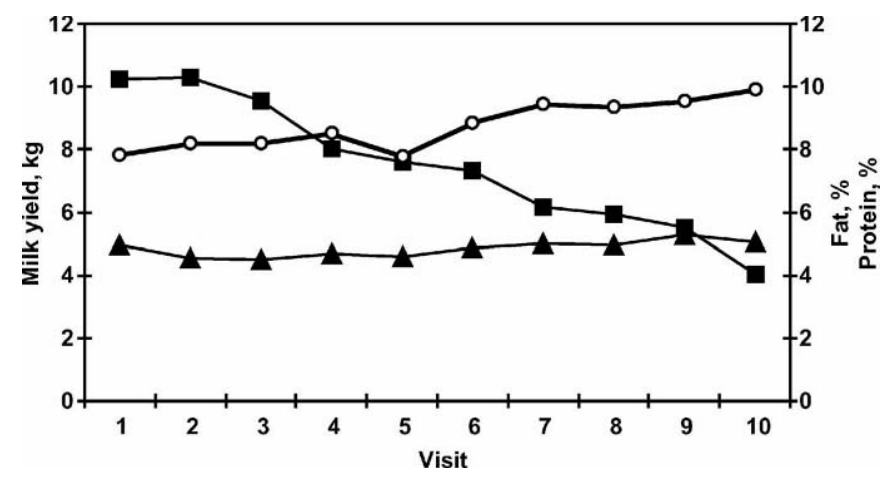

Figure 2. Monthly (based on month of lactation) means for daily milk yield ( $\mathbf{\square})$ and percentages of fat $(\bigcirc)$ and protein $(\boldsymbol{\Delta})$. Monthly standard deviations ranged from 1.9 to $3.4 \mathrm{~kg}$ for milk, 0.86 to 1.87 for fat percentages, and 0.30 to 0.76 for protein percentages.

ally increased during the remainder of lactation. All quarters with SCC $>200,000$ were infected. In addition, $98 \%$ of quarters with SCC $<200,000$ were healthy. These values corresponded to a sensitivity and specificity of 99.1 and $100 \%$, respectively.

Figure 2 illustrates monthly means for milk yield and percentages of protein and fat. Milk yield was initially $\sim 10 \mathrm{~kg} / \mathrm{d}$ and decreased during lactation to about $4 \mathrm{~kg} /$ d. Fat percentage started at about $8 \%$ and finished at about $10 \%$. Protein percentage remained about 5\% during lactation. These values were consistent with buffalo population averages in Italy (Associazione Italiana Allevatori, 1999; Catillo et al., 2002).

\section{Factors Associated with IMI}

Stage of lactation had clear effects on IMI. Consistent with the unadjusted data (Figure 1), the least risk of IMI was at the first visit, early in lactation. The greatest probability for infection was during the 10th month of lactation. The odds ratio indicated an approximate 6.3fold difference in the probability of IMI between the first and 10th visits. Neither term for DIM was significant, presumably because inclusion of the visit factor accounted for stage of lactation effects. Location of the quarter (front or back, left or right) was not associated with the probability of IMI. Significant differences ( $P$ $<0.05$ ) were observed among different months of sampling. Between the extreme low and high months, probability of infection was 4.7 times greater $(P<0.05)$ in September than in February. Probability for IMI tended $(P=0.05)$ to increase with increasing parity number up to $\geq 5$ (results not shown). The reason for the decline after the fifth lactation may be that these buffaloes were a selected group, surviving to fifth lactation, in part, because of their particular robustness. Increased milk yield was associated with increased $(P \leq 0.001)$
Table 2. Mean somatic cell score in healthy and infected quarters and in quarters infected by different pathogens

\begin{tabular}{lll}
\hline & $\begin{array}{l}\text { Least } \\
\text { squares } \\
\text { means }\end{array}$ & $\mathrm{SE}$ \\
\hline Infection status & $2.49^{1}$ & 0.44 \\
Infected & 2.93 & 0.43 \\
Healthy & $2.50^{\mathrm{a}}$ & 0.43 \\
Infected by Streptococcus & $3.62^{\mathrm{b}}$ & 0.47 \\
Infected by coagulase-negative staphylococci & $2.80^{\mathrm{c}}$ & 0.42 \\
Infected by another bacteria & $3.04^{\mathrm{bc}}$ & 0.46 \\
\hline \multicolumn{2}{c}{${ }^{\text {a-c }}$ Means with different superscript letters differ $(P<0.05)}$. \\
\multicolumn{2}{l}{${ }^{1}$ Different $(P<0.05)$ from infected buffaloes. }
\end{tabular}

probability for IMI at the time of the sample with a positive logistic regression coefficient of $\beta=0.073$. Protein percentage was negatively associated $(P \leq 0.02)$ with IMI $(\beta=-0.094)$, and no relationship was detected between IMI and fat percentage.

\section{Factors Associated with SCS}

All of the factors considered had relationships $(P<$ 0.05 ) with SCS, except percentages of protein and fat. Greater SCS were associated with decreased $(P<0.05)$ milk yield, possibly because of the effects of dilution. The mean SCS was greater $(P<0.05)$ in the fore quarters [2.99 vs. 2.43 (rear quarters)] and on the left side [2.93 vs. 2.49 (right side)] of the udder. The first result may be associated with dilution, as the rear quarters of buffalo generally yield more milk than do the fore quarters (A. S. Nanda, Punjab Agricultural University Ludhiana, India, personal communication), which is similar to cattle (Larson, 1995). The mean SCS increased $(P<0.05)$ with DIM and tended to be greater in winter and spring months (December to May) than summer and fall (June to November).

Of primary interest in this study was the relationship between SCS and IMI. Table 2 shows the least squares means for effects of infection status when IMI was defined as either healthy or infected or considered bacterial species. Not surprisingly, SCS was greater $(P<$ 0.05 ) in infected quarters than in quarters without IMI. The difference was not large, however, $<0.5$ SCS. In contrast, infections in dairy cattle (Djabri et al., 2002) and goats (Moroni et al., 2005) have been associated with much greater increases in SCC and SCS. Elevation of the SCS depended on the infecting bacterial species (Table 2). For all species of pathogens examined, SCS in quarters with IMI were greater $(P<0.05)$ than those in uninfected quarters. The greatest SCS was observed in quarters infected by streptococci. Mean SCS for these IMI was 3.62, which was more than a single 
SCS unit greater $(P<0.05)$ than the score in quarters without IMI.

As mentioned previously, most of the streptococci IMI were by Strep. uberis. A meta-analysis of 21 articles in dairy cattle found that Strep. uberis was one of the bacteria associated with the greatest elevation in SCC (Djabri et al., 2002). The least SCS was for the Staphylococcus species (2.80). The CNS were predominantly of the staphylococci group rather than Staph. aureus. Different studies in other host species have demonstrated that Staph. aureus is associated with more greatly elevated SCS than other staphylococci (Djabri et al., 2002; Moroni et al., 2005).

\section{General Discussion}

Among the most striking results of this survey were the elevated rates of IMI in the buffaloes studied and the low SCS. Overall mean SCS was $2.68(\mathrm{SD}=3.25)$, which is much less than is typically found in dairy cattle. Schutz (1994), for example, reported means of $>3.00$ SCS for all of the major breeds of dairy cattle in the United States. This low SCS for the buffalo is especially remarkable considering the observed elevated prevalence of IMI. To make a comparison with dairy cattle, Weller et al. (1992) reported that about $23 \%$ of composite samples evaluated in a study of Israeli dairy cattle were positive for IMI. Mean SCS for those (healthy and infected) cattle ranged from 3.00 to 4.40 , depending on stage of lactation. The thumb rule, indicating use of SCC $>200,000$ as an indicator for IMI in buffaloes (Dhakal et al., 1992; Singh and Ludri, 2001) proved to be remarkably accurate in this study. In fact, simultaneous combination of these 2 findings was particularly unusual, at least relative to dairy cattle. In fact, the reality may be that dairy cattle are the unusual animals. For comparison, a recent study in dairy cattle reported a maximum sensitivity of $60 \%$ for SCS in dairy cattle (Middleton et al., 2004). Even lower sensitivities have been observed using SCS for dairy goats (Boettcher et al., 2005).

The SCS values observed in this study were much more similar to the results reported for beef cattle (Paape et al., 2000) than to those reported for dairy cattle (Weller et al., 1992; Schutz, 1994). Although they reported their results in SCC rather than SCS, Paape et al. (2000) found that even beef cattle infected in all 4 quarters had a mean SCC of $\sim 200,000$ cells $/ \mathrm{mL}$. Thus, much greater average SCC (or SCS) observed in dairy cattle may be because of correlated responses with intensive long-term selection for increased milk yield. One possible biological reason for differences in SCC between buffalo and cattle may be the phagocytic activity of the neutrophils in the various species. Differences between cattle and buffalo in the concentrations of enzyme hydrolases (including lysozyme) have been reported (Sahoo et al., 1998), which could affect the SCC required to reach a given amount of phagocytic activity in each species.

Although numerical difference in SCS between infected and healthy buffaloes tended to be less than in dairy cattle and goats (average difference of only 0.5 SCS, as reported earlier), SCC was still an extraordinarily accurate indicator of subclinical IMI with both sensitivity and specificity $>98 \%$. Because quantification of SCC is not possible in many countries in which buffalo farming is developing, the simple California Mastitis Test may be a practical alternative (Bhindwale et al., 1992; Dhakal, 1994), although some recent work has shown a low correlation between SCC and California Mastitis Test (Thomas, 2004).

Despite the suggested availability of such a simple and accurate indicator of IMI, the results of our study provided little evidence to support the practice of antibiotic treatment of suspected subclinical IMI of buffaloes during lactation. For example, no obvious inferiority in milk yield was observed for infected buffaloes relative to healthy buffaloes. This result contradicts the standard that IMI is associated with decreased production. One could not establish, however, cause and effect from these data. Perhaps the buffaloes with greater production potential were also more susceptible to mastitis. In dairy cattle, increased genetic potential for production is associated with increased incidence of mastitis (Heringstad et al., 2003), and the same association may be true for buffaloes. One way to test for a cause-andeffect relationship between milk yield and IMI would be to monitor a group of buffaloes that started a lactation free of IMI and monitor the change in production associated with new infections. Such an analysis could not be performed with our data, however, because of a lack of buffaloes (only 14) that were completely free of subclinical IMI at the start of the study. Although SCC in healthy and infected buffaloes were distinctly different, the SCC in infected buffaloes might not have been elevated enough to be associated with economic losses because of udder damage. Conversely, treatment of infected buffaloes would lead to increased discard of milk and possibilities for antibiotic resistance.

\section{CONCLUSIONS}

The SCS was found to be a very accurate indicator of IMI in buffalo. The IMI seemed, however, to have little effect on milk yield. For this reason, one cannot strongly advocate antibiotic treatment of subclinical IMI during lactation for buffaloes, given the potential for discarded milk and development of antibiotic resis- 
tance. Dry therapy for prevention may be a more logical approach.

\section{ACKNOWLEDGMENTS}

We are thankful to R. Fedeli for technical assistance and A. S. Nanda (Punjab Agricultural University, Ludhiana, India) for discussions regarding milk yield in buffaloes. This work was supported by Boehringer Ingelheim Italia s.p.a., Divisione Vetmedica, Milan, Italy.

\section{REFERENCES}

Ali, A. K. A., and G. E. Shook. 1980. An optimum transformation for somatic cell concentration in milk. J. Dairy Sci. 63:487-490.

Associazione Italiana Allevatori. 1999. Controlli della Produttività del Latte in Italia. AIA, Rome, Italy.

Badran, A. E. 1985. Genetic and environmental effects on mastitis disease in Egyptian cows and buffaloes. Indian J. Dairy Sci. 38:230-234.

Bansal, B. K., K. A. Singh, R. Mohan, D. V. Joshi, and D. C. Nauriyal. 1995. Incidence of subclinical mastitis in some cow e buffalo herds in Punjab. J. Res. Punjab Agric. Univ. 32:79-81.

Bhindwale, S., P. G. Supekar, and P. C. Shukla. 1992. Subclinical mastitis detection in buffaloes by California Mastitis Test (CMT). Livest. Adviser 17:14-15.

Boettcher, P. J., P. Moroni, G. Pisoni, and D. Gianola. 2005. Application of a finite mixture model to somatic cell scores of Italian goats. J. Dairy Sci. 88:2209-2216.

Catillo, G., N. P. P. Macciotta, A. Carretta, and A. Cappio-Borlino. 2002. Effects of age and calving season on lactation curves of milk production traits in Italian water buffaloes. J. Dairy Sci. 85:1298-1306.

Cerón-Muñoz, M., H. Tonhati, J. Duarte, J. Oliveira, M. Mun̂ozBerrocal, and H. Jurado-Gámez. 2002. Factors affecting somatic cell counts and their relations with milk and milk constituent yield in Buffaloes. J. Dairy Sci. 85:2885-2889.

Chander, S., and K. K. Baxi. 1975. Note on diagnosis and treatment of subclinical mastitis in buffaloes. Indian Vet. J. 52:847-849.

Costa, E. O., F. Garino, Jr., E. T. Watanabe, A. R. Ribeiro, J. Silva, P. Vezon, S. H. Gabaldi, N. R. Benites, P. S. Baruselli, and A. Paske. 1997. Evaluation of the CMT positivity and microbiological status of the mammary gland over the different lactation phases in buffalo cows (Bubalus bubalis). Proc. World Buffalo Cong., Caserta, Italy 5:631-634.

Dhakal, I. P. 1994. Prevalence of subclinical mastitis in buffaloes at drying off and post calving stages. Vet. Rev. Phakribas Agric. Centre, Dhankuta 9 and 10:18-22.

Dhakal, I. P., M. O. Kapur, and A. Sharma. 1992. Significance of differential somatic cell counts in milk for the diagnosis of subclinical mastitis in buffaloes using foremilk and stripping milk. Indian J. Anim. Health 31:39-43.
Djabri, B., N. Bareille, F. Beaudeau, and H. Seegers. 2002. Quarter milk somatic cell count in infected dairy cows: A meta-analysis. Vet. Res. 33:335-357.

Heringstad, B., G. Klemetsdal, and T. Steine. 2003. Selection responses for clinical mastitis and protein yield in two Norwegian dairy cattle selection experiments. J. Dairy Sci. 86:2990-2999.

Jaffery, M. S., and A. R. Rizvi. 1975. Aetiology of mastitis in NiliRavi buffaloes of Pakistan. Acta Trop. 32:75-78.

Kalra, D. S., and M. R. Dhanda. 1964. Incidence of mastitis in cows and buffaloes in North West India. Vet. Rec. 76:219-222.

Larson, B. 1995. Lactation. Iowa State University Press, Ames.

Middleton, J. R., D. Hardin, B. Steevens, R. Randle, and J. W. Tyler. 2004. Use of somatic cell counts and California mastitis test results from individual quarter milk samples to detect subclinical intramammary infection in dairy cattle from a herd with a high bulk tank somatic cell count. J. Am. Vet. Med. Assoc. 224:419-423.

Moroni, P., G. Pisoni, G. Ruffo, and P. J. Boettcher. 2005. Risk factors for intramammary infections and relationship with somatic-cell counts in Italian dairy goats. Prev. Vet. Med. 69:163-173.

Naiknaware, H. S., D. D. Shelke, D. P. Bhalerao, D. V. Keskar, S. Jagadesh, and L. K. Sharma. 1998. Prevalence of subclinical mastitis in buffaloes in and around Mumbai. Indian Vet. J. 75:291-292.

National Mastitis Council. 1999. Laboratory Handbook on Bovine Mastitis. National Mastitis Council, Madison, WI.

Paape, M. J., M. I. Duenas, R. P. Wettemann, and L. W. Douglass. 2000. Effects of intramammary infection and parity on calf weaning weight and milk quality in beef cows. J. Anim. Sci. 78:2508-2514.

Paranjabe, V. L., and A. M. Das. 1986. Mastitis among buffalo population of Bombay-A bacteriological report. Indian Vet. J. 63:438-441.

Pool, M. H., L. L. G. Janss, and T. H. E. Meuwissen. 2000. Genetic parameters of Legendre polynomials for first parity lactation curves. J. Dairy Sci. 83:2640-2649.

Sahoo, G., T. More, and V. K. Singh. 1998. A comparative study on certain enzymes of the granulocyte from different ruminant species. Comp. Immunol. Microbiol. Infect. Dis. 21:319-325.

Saini, S. S., J. K. Sharma, and M. S. Kwatra. 1994. Prevalence and aetiology of subclinical mastitis among crossbreed cows and buffaloes in Punjab. Indian J. Dairy Sci. 47:103-107.

SAS. 1996. SAS/STAT User's Guide, release 6.03 edition. SAS Inst., Inc., Cary, NC.

Schutz, M. M. 1994. Genetic evaluation of somatic cell scores for United States dairy cattle. J. Dairy Sci. 77:2113-2129.

Singh, M., and R. S. Ludri. 2001. Somatic cell counts in Murrah buffaloes (Bubalus bubalis) during different stages of lactation, parity and season. Asian-Australas. J. Anim. Sci. 14:189-192.

Thomas, C. S. 2004. Milking management of dairy buffaloes. Ph.D. Diss., Swedish Univ. Agric. Sci., Uppsala, Sweden.

Wanasinghe, D. D. 1985. Mastitis among buffaloes in Sri Lanka. Proc. First World Buffalo Congr., Cairo, Egypt 4:1331-1333.

Weller, J. I., A. Saran, and Y. Zeliger. 1992. Genetic and environmental relationships among somatic cell count, bacterial infection, and clinical mastitis. J. Dairy Sci. 75:2532-2540. 